\title{
Effect of reduced energy density of close-up diets on dry matter intake, lactation performance and energy balance in multiparous Holstein cows
}

Wenming Huang ${ }^{\dagger}$, Yujia Tian ${ }^{\dagger}$, Yajing Wang, Aminamu Simayi, Amingguli Yasheng, Zhaohai Wu, Shengli Li and Zhijun $\mathrm{CaO}^{*}$

\begin{abstract}
Energy intake prepartum is critically important to health, milk performance, and profitability of dairy cows. The objective of this study was to determine the effect of reduced energy density of close-up diets on dry matter intake (DMI), lactation performance and energy balance (EB) in multiparous Holstein cows which were housed in a free-stall barn and fed for ad libitum intake. Thirty-nine dry cows were blocked and assigned randomly to three groups fed a high energy density diet $\left[H D, n=13 ; 6.8 \mathrm{MJ}\right.$ of net energy for lactation $\left(N E_{L}\right) / \mathrm{kg} ; 14.0 \%$ crude protein $(C P)]$, or a middle energy density diet $(M D, n=13 ; 6.2 \mathrm{MJNE} / \mathrm{kg} ; 14.0 \% \mathrm{CP})$, or a low energy density diet (LD, $\mathrm{n}=13 ; 5.4 \mathrm{MJ} \mathrm{NE} / \mathrm{kg} ; 14.0 \% \mathrm{CP}$ ) from d 21 before expected day of calving. After parturition, all cows were fed the same lactation diet to $\mathrm{d} 70$ in milk (DIM). The DMI and $\mathrm{NE}_{\mathrm{L}}$ intake prepartum were decreased by the reduced energy density diets $(P<0.05)$. The LD group consumed $1.3 \mathrm{~kg} / \mathrm{d}(\mathrm{DM})$ more diet compared with HD group in the last $24 \mathrm{~h}$ before calving. The milk yield and the postpartum DMl were increased by the reduced energy density diet prepartum $(P<0.05)$. The changes in BCS and BW prepartum and postpartum were not affected by prepartum diets. HD group had higher milk fat content and lower lactose content compared with LD group during the first 3 wk of lactation $(P<0.05)$. The energy consumption for HD, MD and LD groups were $149.8 \%, 126.2 \%$ and $101.1 \%$ of their calculated energy requirements prepartum $(P<0.05)$, and $72.7 \%, 73.1 \%$ and $75.2 \%$ during the first 4 wk postpartum, respectively. In conclusion, the low energy density prepartum diet was effective in controlling $\mathrm{NE}_{\mathrm{L}}$ intake prepartum, and was beneficial in increasing DMl and milk yield, and alleviating negative EB postpartum.
\end{abstract}

Keywords: Dietary energy density, Dry matter intake, Energy balance, Lactation performance, Transition cow

\section{Introduction}

The transition period is the most challenging time in the production cycle of dairy cows because of depressed dry matter intake (DMI) and marked changes in metabolism that support late gestation, parturition and the onset of milk synthesis. The abrupt increase in energy demands after parturition results in a negative energy balance (NEB) which can be met by mobilization of body fat reserves and by a decrease in insulin-dependent glucose utilization in non-mammary tissues [1]. Extensive mobilization of body fat reserves is associated with metabolic disorders such as fatty liver and ketosis.

\footnotetext{
*Correspondence: lisheng0677@163.com; caozhijun@cau.edu.cn ${ }^{\dagger}$ Equal contributors

State Key Laboratory of Animal Nutrition, College of Animal Science and Technology, China Agricultural University, Beijing 100193, China
}

DMI rather than milk yield is the major driver of NEB [2]. Therefore, nutritional management during the transition period designed to increase postpartum DMI might be a potential strategy to alleviate the negative effect of NEB on performance as well as related metabolic disorders.

Approximately $3 \mathrm{wk}$ before parturition, DMI starts to decline and further reduces dramatically in the last week before parturition [3-5]. On the other hand, in the last month of pregnancy the energy requirement of the dairy cow increases by about $20 \%$ to support gravid uterus growth [6]. As DMI decline in late gestation is practically unavoidable, increasing the energy density of the close-up dry period diet should help to maintain energy intake [7]. NRC (2001) recommended an approximately 5.2 MJ $\mathrm{NE}_{\mathrm{L}} / \mathrm{kg}$ of DM diet for far-off dry period cows, 
and a 6.4 to $6.8 \mathrm{MJ} \mathrm{NE} / \mathrm{kg}$ of $\mathrm{DM}$ diet for close-up cows, so as to allow the rumen and its microbes to adapt to the freshly calved diet [8]. Some researchers have suggested that prepartum DMI was positively correlated with postpartum DMI and prepartum DMI should be maximized to improve postpartum performance and health $[4,9]$. In contrast to this viewpoint, most of the last decade's research has shown that over consumption of energy prepartum often resulted in a slower increase in DMI postpartum compared with cows on a restricted intake $[5,10,11]$ or fed on a low energy density diet containing wheat straw $[11,12]$ and this was detrimental to cow health and liver function postpartum $[11,13,14]$. Lower DMI postpartum intensifies NEB and the mobilization of body fat results in more triacylglycerol and ketone deposition in the liver. Fatty liver has been linked to an increased incidence of metabolic disorders and poor milk yield [15]. Most of the above studies used moderate or high energy density diets with restricted DMI to control energy intake or cows were housed in a tie-stall barn, and the cows may be in a hungry condition and eager to consume more. These experimental results do not reflect the true energy intake and metabolism of transition cows housed in a free-stall barn on commercial farms, however, because transition cows normally have bunk space with free access to feed and water. Further study is needed to address this issue which is critical for dairy management.

It is very common to use moderate or even high energy density transition diets in Chinese dairy farms and the incidence of metabolic diseases is sometimes very high. However, China is short of high quality forage and abundant in low quality forage (Leymus chinensis hay, corn stover and wheat straw). Our hypothesis was that: low energy density diets containing more Leymus chinensis hay could control energy intake prepartum, having the same or better effect on EB postpartum compared to high energy density diets with restricted DMI. The objective of this study was to determine a suitable close-up dietary energy density for multiparous Holstein cows with ad libitum access to feed and housed in a free-stall barn.

\section{Materials and methods \\ Animals and design}

Animal care and use were approved and conducted in accordance with the practices outlined in the Guide for the Care and Use of Agriculture Animals in Agriculture Research and Teaching [16]. Thirty-nine New Zealand multiparous Holstein cows (average contents of milk fat, protein, and lactose were $5.49 \pm 0.99 \%, 3.59 \pm 0.38 \%$ and $4.98 \pm 0.29 \%$, respectively) were enrolled in the study. Cows were dried off at $60 \mathrm{~d}$ and moved into an experimental barn $35 \mathrm{~d}$ before expected parturition which has
48 free stalls with length $\times$ width $=230 \mathrm{~cm} \times 110 \mathrm{~cm}$, and the feed bunk space was $110 \mathrm{~cm}$. The stocking density was about $81 \%$ (39 cows/48 free stalls). Cows were grouped according to milk production in the first 3 mo of the previous parity, body weight (BW), body condition score (BCS) and expected calving date and assigned randomly into 1 of 3 dietary treatments. All cows were enrolled in experiment at the same time. The average date before expected parturition for the 3 groups were $21.4 \pm 2.5 \mathrm{~d}, 21.2 \pm 2.7 \mathrm{~d}$, and $21.1 \pm 2.5 \mathrm{~d}$ when the experiment was started. The experiment was conducted from November, 2012 to February, 2013, and the average temperature and humidity during the prepartum and postpartum phases were $-3.7 \pm 6.3^{\circ} \mathrm{C},-7.4 \pm 4.9^{\circ} \mathrm{C}$, and $46.3 \pm 7.2 \%, 43.6 \pm 6.3 \%$, respectively.

From dry off to d 22 before expected parturition, all cows were fed the same far-off dry period diet $\left(\mathrm{NE}_{\mathrm{L}} 5.4 \mathrm{MJ} / \mathrm{kg}\right.$; Table 1). From d 21 before expected day of calving until parturition, cows were blocked and assigned randomly to three groups fed a high energy density diet [HD treatment, $\mathrm{n}=13 ; 6.8 \mathrm{MJ}$ of net energy for lactation $\left(\mathrm{NE}_{\mathrm{L}}\right) / \mathrm{kg} ; 14.0 \%$ crude protein $(\mathrm{CP})$ ], or a middle energy density diet (MD treatment, $n=13$; 6.2 $\mathrm{MJ} \mathrm{NE} / \mathrm{kg} ; 14.0 \% \mathrm{CP}$ ), or a low energy density diet (LD treatment, $\mathrm{n}=13 ; 5.4 \mathrm{MJ} \quad \mathrm{NE}_{\mathrm{L}} / \mathrm{kg} ; 14.0 \% \mathrm{CP}$; Table 1). The Leymus chinensis hay was the first batch of materials loaded into TMR mixer and being chopped into small particles, and then mixed with corn silage and concentrate. Different amounts of water were added to each of the three diets to adjust DM content within 51\%$52 \%$. After parturition, all the cows were provided with the same lactation diet to 70 DIM (Table 1).

Cows were housed in a free-stall barn with delivery room, and were fed the diets as a TMR ad libitum throughout the experiment, which was offered once (at $1600 \mathrm{~h}$ ) daily prepartum and twice (at 0730 and $1430 \mathrm{~h}$ ) postpartum. Orts were controlled less than $8 \%$. Cows were milked 3 times daily (at 0070, 1400, and $2030 \mathrm{~h}$ ) in a double-48 parallel milking parlor.

\section{Data collections, sampling procedures, and data analysis}

DMI of individual cow was determined every day from $\mathrm{d}-21$ to $\mathrm{d} 35$ by roughage intake control feeders (Insentec B.V., Marknesse, the Netherlands) with 48 feed bins. All cows were kept in one group and with access to different feed bins. For each visit to the bin, the system recorded the cow number, bin number, initial and final times, weights and calculated the visit duration and intake. The system's minimum range is $0.1 \mathrm{~kg}$, and it showed a high specificity (100\%) and sensitivity (100\%) for the feed bins and cow identification [17]. Diets were sampled weekly to determine DM contents. The particle size distribution of the TMR was determined weekly using a Penn State Particle Separator to detect sorting. Briefly, the 
Table 1 Composition and analysis of diets fed to Holstein cows during the dry and lactating periods

\begin{tabular}{|c|c|c|c|c|c|}
\hline \multirow[t]{2}{*}{ Item } & \multirow{2}{*}{$\begin{array}{c}\text { Far-off } \\
\text { diet }\end{array}$} & \multicolumn{3}{|c|}{ Close-up diets $^{1}$} & \multirow{2}{*}{$\begin{array}{c}\text { Lactation } \\
\text { diet }^{2}\end{array}$} \\
\hline & & HD & MD & $\overline{\text { LD }}$ & \\
\hline \multicolumn{6}{|l|}{ Ingredients, \% DM } \\
\hline Leymus chinensis hay & 42.8 & 13.3 & 21.7 & 31.3 & - \\
\hline Alfalfa hay & - & 8.4 & 8.4 & 8.4 & 17.2 \\
\hline Whole corn silage & 24.7 & 21.0 & 21.1 & 21.0 & 21.0 \\
\hline Corn & 12.0 & 23.2 & 14.4 & 2.0 & 20.0 \\
\hline Extruded soybean & - & - & - & - & 2.6 \\
\hline Soybean meal & 2.1 & 4.5 & 4.0 & 3.7 & 5.8 \\
\hline Rapeseed meal & 4.5 & 4.0 & 4.0 & 4.0 & 1.3 \\
\hline Cottonseed meal & 5.0 & 4.0 & 4.3 & 4.5 & 1.3 \\
\hline Apple pomace & 9.2 & 5.7 & 7.3 & 11.4 & 2.5 \\
\hline Whole cottonseed & - & 3.3 & 3.3 & 3.3 & 10.4 \\
\hline DDGS & 4.1 & 4.0 & 4.0 & 4.0 & 10.0 \\
\hline Palm kernel meal & 5.1 & 3.3 & 3.3 & 3.3 & - \\
\hline Beet pulp meal & - & - & - & - & 3.5 \\
\hline Calcium carbonate & 1.2 & 1.9 & 1.9 & 1.9 & 1.0 \\
\hline Close-up premix ${ }^{3}$ & 0.1 & 0.4 & 0.4 & 0.4 & - \\
\hline Lactation premix ${ }^{4}$ & - & - & - & - & 7 \\
\hline Bergafat $^{5}$ & - & 2.2 & 0.9 & - & 1.6 \\
\hline Yeast culture ${ }^{6}$ & 0.2 & 0.9 & 0.9 & 0.9 & 0.4 \\
\hline Sodium bicarbonate & - & - & - & - & 0.9 \\
\hline \multicolumn{6}{|l|}{ Analysis } \\
\hline $\mathrm{DM}, \%$ & 51.9 & 51.5 & 51.5 & 51.6 & 52.1 \\
\hline$C P, \%$ of $D M$ & 12.6 & 14.0 & 14.0 & 14.0 & 18.2 \\
\hline $\mathrm{NDF}, \%$ of $\mathrm{DM}$ & 53.3 & 37.4 & 42.9 & 49.8 & 31.7 \\
\hline$A D F, \%$ of $D M$ & 32.4 & 23.2 & 26.8 & 31.5 & 19.8 \\
\hline $\mathrm{NFC}, \%$ of $\mathrm{DM}$ & 22.8 & 35.0 & 30.4 & 23.9 & 36.9 \\
\hline Crude fat, $\%$ of DM & 3.1 & 5.6 & 4.3 & 3.3 & 5.7 \\
\hline$N E_{L}, M J / k g D M$ & 5.4 & 6.8 & 6.2 & 5.4 & 7.2 \\
\hline $\mathrm{ME}, \mathrm{MJ} / \mathrm{kg} \mathrm{DM}$ & 8.7 & 10.7 & 10.0 & 8.8 & 11.1 \\
\hline
\end{tabular}

${ }^{1} H D$ high energy density diet, $M D$ middle energy density diet, $L D$ low energy density diet.

${ }^{2}$ Lactation diet was fed to cows from parturition to $70 \mathrm{~d}$ in milk.

${ }^{3}$ Close-up premix contained (per $\mathrm{kg}$ of premix; DM basis): 2,200,000 IU of vitamin $A, 550,000 \mathrm{IU}$ of vitamin $\mathrm{D}_{3}, 20,000 \mathrm{IU}$ of vitamin $E, 2,000 \mathrm{mg}$ of vitamin PP, 3,750 mg Cu, 5,720 mg Mn, 14,850 mg Zn, $150 \mathrm{mg} \mathrm{l}, 180 \mathrm{mg} \mathrm{Se}$, $120 \mathrm{mg}$ Co.

${ }^{4}$ Lactation premix contained (per kg of premix; DM basis): $1,000,000 \mathrm{IU}$ of vitamin $A, 280,000 \mathrm{IU}$ of vitamin $\mathrm{D}_{3}, 10,000 \mathrm{IU}$ of vitamin $\mathrm{E}, 1,000 \mathrm{mg}$ of vitamin PP, 3,250 mg Cu, 4,800 mg Mn, 12,850 mg Zn, $140 \mathrm{mg} \mathrm{I,} 150 \mathrm{mg} \mathrm{Se}$, $110 \mathrm{mg}$ Co.

${ }^{5}$ Fractionated palm fatty acids (Berg + Schmidt, Hamburg, Germany).

${ }^{6}$ Diamond V XP, Diamond V Mills, Inc.

particle size distribution of diets and orts were compared to determine if sorting occurred $(\geq 15$ percentage unit change on the19-mm screen) $[18,19]$.

BW was measured at $\mathrm{d}-21,-14,-7 \mathrm{~d}$ relative to expected parturition and at 1, 7, 14, 21, 28, 35 DIM
(WOW, XR3000, Tru-Test, New Zealand). Dry cows were weighed at $1430 \mathrm{~h}$, and lactating cows were also weighed at $1430 \mathrm{~h}$ after milking and before diets deliver. BCS was assessed independently by two individuals on a 1 to 5 scale [20].

Cows were milked three times daily, and individual milk production except colostrum was recorded at each milking (Bou-Matic, United States). The quantity of milk was adjusted to an equal energy basis using the formula: four-percent FCM yield $=(0.4 \times$ milk yield $)+[15 \times(\%$ fat $/ 100) \times$ milk yield]. Milk samples were obtained using milk meters at the afternoon milking on 7, 14, 21, 28, 35 and 42 DIM. Milk components (protein, fat, lactose) were determined at Beijing Dairy Cattle Center using a near-infrared reflectance spectroscopy analyzer (Seris300 CombiFOSS; Foss Electric, Hillerød, Denmark).

Energy balance (EB) was calculated individually for each cow according to NRC (2001) [8]. All equations used units of megajoules per kilogram. $\mathrm{NE}_{\mathrm{L}}$ intake (NEI) was determined by multiplying DMI by the mean $\mathrm{NE}_{\mathrm{L}}$ density of the diet. Net energy required for maintenance $\left(\mathrm{NE}_{\mathrm{M}}\right)$ was calculated as $\mathrm{BW}^{0.75} \times 0.08 \times 120 \%$ prepartum and $\mathrm{BW}^{0.75} \times 0.08 \times 110 \%$ postpartum. Net energy required for pregnancy $\left(\mathrm{NE}_{\mathrm{P}}\right)$ was calculated as $[(0.00318 \times$ day of gestation - 0.0352) $\times$ (calf birth weight/45)]/ 0.218. Net energy required for lactation $\left(\mathrm{NE}_{\mathrm{L}}\right)$ was calculated as $(0.0929 \times \mathrm{fat} \%+0.0563 \times$ protein $\%+0.0395 \times$ lactose $\%) \times$ milk. The equation used to calculate prepartum EB was EBPRE $=$ NEI $-\left(\mathrm{NE}_{\mathrm{M}}+\right.$ $\mathrm{NE}_{\mathrm{P}}$ ). The equation used to calculate postpartum $\mathrm{EB}$ was EBPOST $=\mathrm{NEI}-\left(\mathrm{NE}_{\mathrm{M}}+\mathrm{NE}_{\mathrm{L}}\right)$.

\section{Statistical analysis}

Five cows did not complete the study: 1 cow had a dead fetus, 3 cows had mastitis and 1 cow had a displaced abomasum. Thus, 34 cows (HD, $\mathrm{n}=11$; $\mathrm{MD}, \mathrm{n}=11$; LD, $\mathrm{n}=12$ ) completed the experiment and were used in the analysis.

Individual daily DMI, NEI, NDF intake and milk yield values were condensed to weekly means before analysis; the yields and contents of milk fat, protein, lactose and EB were calculated using the weekly mean. To avoid problems with fitting covariance structure, data for DMI, NEI, NDF intake, and EB were analyzed separately for the prepartum and postpartum periods. The DMI, NEI, NDF intake, milk yield, milk components and EB were evaluated using the MIXED procedure of SPSS 16.0 (SPSS Inc.) for repeated measures with the following model: $\mathrm{Y}_{\mathrm{ikn}}=\mu+\mathrm{W}_{\mathrm{i}}+\mathrm{T}_{\mathrm{k}}+\mathrm{WT}_{\mathrm{ik}}+\mathrm{C}_{(\mathrm{ik}) \mathrm{n}}$, where $\mathrm{Y}_{\mathrm{ikn}}=\mathrm{an}$ observation from the $i^{\text {th }}$ week relative to calving, $\mathrm{k}^{\text {th }}$ treatment, and $n^{\text {th }}$ cow; $\mu=$ the grand mean; $W_{i}=$ effect of the $\mathrm{i}^{\text {th }}$ week; $\mathrm{T}_{\mathrm{k}}=$ effect of the $\mathrm{k}^{\text {th }}$ treatment; $\mathrm{WT}_{\mathrm{ik}}=$ effect of the week by treatment interaction; and $\mathrm{C}_{(\mathrm{ik}) \mathrm{n}}=$ random experimental error from the $\mathrm{n}^{\text {th }}$ cow nested 
within the $\mathrm{i}^{\text {th }}$ week and $\mathrm{k}^{\text {th }}$ treatment. Repeated statement was used for variables measured over time. Covariance structures including autoregressive (1), compound symmetry, and unstructured were tested. Autoregressive (1) yielded the lowest Akaike's criterion and was finally used in our model. DMI, NEI and NDF intake for $-48 \mathrm{~h}$ to $48 \mathrm{~h}, \mathrm{BW}, \mathrm{BCS}$, and weekly EB were evaluated by One-Way ANOVA procedure of SPSS 16.0 (SPSS Inc.). Least squares means were computed and are presented throughout. A value of $P<0.05$ was set as the significance level.

\section{Results}

\section{DMI and NE}

The total average DMI and NEI prepartum were decreased by the reduced energy density diets $(P<0.05$; Table 2). During the last week before parturition, the DMI of the 3 groups was not affected $(P=0.22)$ and all declined markedly, but the NEI for LD group was lower than that of HD and MD groups $(P<0.05)$. Although HD group was fed a high energy density diet, the DMI $(P=0.70)$ and NEI $(P=0.99)$ were not affected in the last $24 \mathrm{~h}$ before parturition. The average NDF intake was increased by the reduced energy density diets during the whole close-up period and the last week before parturition $(P<0.05)$. The total average DMI and NEI of LD group were higher than that of HD group $(P<0.05)$ during the first 5 wk of lactation, and higher in LD group compared with $\mathrm{HD}$ and MD groups from 4 to $5 \mathrm{wk}$ of lactation $(P<0.05)$.

\section{$\mathrm{BCS}$ and $\mathrm{BW}$}

Pretrial BCS and BW were not different among dietary treatment groups (Table 3; $P>0.05$ ). The change in BCS and BW prepartum showed no significant differences among the 3 treatments $(P>0.05)$. Although all the 3 treatments gained $\mathrm{BW}$ prepartum, the MD group had no change in BCS and LD group lost a little BCS. The loss of $\mathrm{BCS}(P=0.71)$ and $\mathrm{BW}(P=0.55)$ for LD group was numerically lower than $\mathrm{HD}$ and MD groups during the first $5 \mathrm{wk}$ of lactation.

\section{Milk yield and composition}

The average milk yield for MD and LD groups was higher than HD group during the first 10 wk (Table 4; $P<0.05)$. The $4 \%$ FCM yield for LD group was $2.1 \mathrm{~kg} / \mathrm{d}$ less than HD group during the first $3 \mathrm{wk}(P>0.05)$, and was similar among the 3 groups during the first $6 \mathrm{wk}$ $(P>0.05)$. The milk fat content of HD group was higher than MD and LD groups during the first $3 \mathrm{wk}$ and first $6 \mathrm{wk}(P<0.05)$, and milk lactose content during the first $3 \mathrm{wk}$ and milk lactose yield during the first 6 wk were lower than these 2 treatments $(P<0.05)$. Energy density of the diets demonstrated no effect on milk protein content, milk fat yield and protein yield during the experiment $(P>0.05)$.

\section{Energy balance}

In the close-up dry period, there was significant difference among the 3 treatments in EB (Table 5; $P<0.001$ ). HD, MD and LD groups consumed 30.1, 15.9 and $1.3 \mathrm{MJ} / \mathrm{d}$ more than the prepartum $\mathrm{NE}_{\mathrm{L}}$ requirement, respectively; and achieved $149.8 \%, 126.2 \%$ and $101.1 \%$ of their calculated energy requirement, respectively. During the last week before calving, LD group consumed $87.4 \%$ of their energy requirement and the other 2 treatments both exceeded $100 \%$. LD group had a milder NEB compared to the other 2 treatments during the first week of lactation. During the first $4 \mathrm{wk}$ postpartum, HD, MD and LD groups achieved $72.7 \%, 73.1 \%$ and $75.2 \%$ of their calculated energy requirement, respectively. In all treatments, the most marked NEB appeared in approximately the third and fourth week.

\section{Discussion}

\section{$\mathrm{DMI}$ and NEI}

The average DMI for the 3 treatments was $12.6-14.3 \mathrm{~kg} /$ d prepartum, which was higher than our previous study with cows in a tie-stall barn $(12.3 \mathrm{~kg} / \mathrm{d}$ in cool autumn and $8.0 \mathrm{~kg} / \mathrm{d}$ in hot summer) [21]. In Janovick's study [12], the cows housed in tie stalls and fed the same high $\mathrm{NE}_{\mathrm{L}}$ diet $(6.8 \mathrm{MJ} / \mathrm{kg})$ had less DMI (13.1 v. $\left.14.3 \mathrm{~kg} / \mathrm{d}\right)$ compared with our study, but those fed a similar low $\mathrm{NE}_{\mathrm{L}}$ diet $(5.2$ v. $5.4 \mathrm{MJ} / \mathrm{kg}$ ) had a slightly higher DMI $(12.8$ v. $12.6 \mathrm{~kg} / \mathrm{d})$, and the $\mathrm{BW}$ of our experimental cows were much lower (approximately 650 v. $730 \mathrm{~kg}$ ). Leymus chinensis hay has high NDF $(68 \% \sim 74 \%$, DM) and $\mathrm{ADF}(35 \% \sim 40 \%, \mathrm{DM})$ contents, and it's effective ruminal NDF degradability is $26 \% \sim 31 \%$, and is abundant in the Northeast of China. In the current study, cows fed a low energy density diet containing much Leymus chinensis hay had a significantly lower DMI prepartum. In the last $48 \mathrm{~h}$ before calving, however, the DMI for the 3 treatments had no significant difference. The results revealed that a high NDF content diet gave a small change in DMI prepartum. Other studies have shown that diets supplemented with much wheat straw had lower DMI and DMI decline rate prepartum [11,22,23]. The average proportion of the19-mm screen for diets of HD, MD, LD groups were $23.2 \%, 20.4 \%$ and $14.7 \%$ as fed basis prepartum, respectively; and they were $35.1 \%, 29.8 \%$ and $19.3 \%$ for orts of HD, MD, LD groups, respectively. All the changes on the19-mm screen were less than 15 percentage unit, indicating no sorting has occurred.

58.6-60.7 MJ/d is recommended by NRC (2001) for NEI of close-up dairy cows [8]. In our study, the average prepartum NEI was 97.1, 83.3 and $68.6 \mathrm{MJ} / \mathrm{d}$ for HD, 
Table 2 Effect of energy density of close-up dry period diets on DMI and (NEI) in Holstein cows

\begin{tabular}{|c|c|c|c|c|c|c|c|}
\hline \multirow[t]{2}{*}{ Item } & \multicolumn{3}{|c|}{ Dietary treatment ${ }^{1}$} & \multirow[t]{2}{*}{ SEM } & \multicolumn{3}{|c|}{$P$-value } \\
\hline & HD & MD & LD & & Diet & Time & Interaction \\
\hline \multicolumn{8}{|l|}{$\mathrm{DMI}, \mathrm{kg} / \mathrm{d}$} \\
\hline \multicolumn{8}{|l|}{ Prepartum } \\
\hline$W k-3$ to -1 & $14.3^{\mathrm{a}}$ & $13.6^{\mathrm{b}}$ & $12.6^{c}$ & 0.14 & $<0.001$ & $<0.001$ & 0.87 \\
\hline Wk-1 & 12.3 & 11.8 & 11.1 & 0.29 & 0.22 & & \\
\hline $\mathrm{H}-48$ to -25 & 10.9 & 11.0 & 9.6 & 0.46 & 0.37 & & \\
\hline $\mathrm{H}-24$ to 0 & 5.0 & 5.6 & 6.3 & 0.61 & 0.7 & & \\
\hline \multicolumn{8}{|l|}{ Postpartum } \\
\hline Wk 1 to 5 & $18.8^{\mathrm{b}}$ & $19.1^{\mathrm{ab}}$ & $19.7^{\mathrm{a}}$ & 0.13 & 0.04 & $<0.001$ & 0.37 \\
\hline HO to 24 & 10.5 & 10.4 & 11.1 & 0.82 & 0.95 & & \\
\hline H 25 to 48 & 11.9 & 12.1 & 12.6 & 0.7 & 0.93 & & \\
\hline Wk 1 to 3 & 17.9 & 18.1 & 18.3 & 0.18 & 0.86 & $<0.001$ & 0.67 \\
\hline Wk 4 to 5 & $20.1^{b}$ & $20.7^{b}$ & $21.7^{\mathrm{a}}$ & 0.17 & 0.001 & 0.12 & 0.66 \\
\hline \multicolumn{8}{|l|}{$\mathrm{NEl}, \mathrm{MJ} / \mathrm{d}$} \\
\hline \multicolumn{8}{|l|}{ Prepartum } \\
\hline$W k-3$ to -1 & $97.1^{\mathrm{a}}$ & $83.3^{b}$ & $68.6^{c}$ & 0.83 & $<0.001$ & $<0.001$ & 0.42 \\
\hline$W k-1$ & $83.3^{\mathrm{a}}$ & $72.4^{b}$ & $60.2^{c}$ & 2.22 & $<0.001$ & & \\
\hline $\mathrm{H}-48$ to -25 & $73.9^{\mathrm{a}}$ & $67.3^{\mathrm{a}}$ & $52.0^{\mathrm{b}}$ & 3.31 & 0.01 & & \\
\hline $\mathrm{H}-24$ to 0 & 34.1 & 33.9 & 34.3 & 3.64 & 0.99 & & \\
\hline \multicolumn{8}{|l|}{ Postpartum } \\
\hline Wk 1 to 5 & $136.0^{\mathrm{b}}$ & $138.1^{\mathrm{ab}}$ & $142.3^{\mathrm{a}}$ & 0.95 & 0.03 & $<0.001$ & 0.67 \\
\hline HO to 24 & 76.3 & 75.3 & 80.1 & 6.23 & 0.87 & & \\
\hline $\mathrm{H} 25$ to 48 & 86.1 & 97.9 & 91.0 & 5.06 & 0.93 & & \\
\hline Wk 1 to 3 & 129.2 & 130.5 & 132.2 & 1.40 & 0.72 & $<0.001$ & 0.9 \\
\hline Wk 4 to 5 & $145.2^{b}$ & $149.4^{b}$ & $156.9^{\mathrm{a}}$ & 1.25 & 0.001 & 0.12 & 0.64 \\
\hline \multicolumn{8}{|l|}{$\mathrm{NDF}, \mathrm{kg} / \mathrm{d}$} \\
\hline \multicolumn{8}{|l|}{ Prepartum } \\
\hline$W k-3$ to -1 & $5.3^{c}$ & $5.8^{\mathrm{b}}$ & $6.3^{\mathrm{a}}$ & 0.07 & $<0.001$ & $<0.001$ & 0.99 \\
\hline$W k-1$ & $4.6^{b}$ & $5.1^{\mathrm{ab}}$ & $5.5^{\mathrm{a}}$ & 0.14 & 0.03 & & \\
\hline $\mathrm{H}-48$ to -25 & 4.1 & 4.7 & 4.8 & 0.20 & 0.32 & & \\
\hline $\mathrm{H}-24$ to 0 & 1.9 & 2.4 & 3.1 & 0.28 & 0.19 & & \\
\hline \multicolumn{8}{|l|}{ Postpartum } \\
\hline Wk 1 to 5 & $6.0^{\mathrm{b}}$ & $6.1^{\mathrm{ab}}$ & $6.2^{\mathrm{a}}$ & 0.04 & 0.04 & $<0.001$ & 0.40 \\
\hline HO to 24 & 3.3 & 3.3 & 3.5 & 0.26 & 0.95 & & \\
\hline $\mathrm{H} 25$ to 48 & 3.8 & 3.9 & 4.0 & 0.22 & 0.95 & & \\
\hline
\end{tabular}

${ }^{1} \mathrm{HD}$ high energy density diet, $M D$ middle energy density diet, $L D$ low energy density diet.

$\mathrm{a}, \mathrm{b}, \mathrm{c}$ Values within a row with different superscripts differ significantly at $P<0.05$.

$\mathrm{MD}$ and LD, respectively, which were higher than the energy requirements recommended by NRC (2001) [8]. Other studies have also confirmed that close-up cows fed with moderate or low energy density diets would easily consume more energy relative to their requirements if DMI is not limited [11,24]. But the energy consumption of LD group fed a higher level of Leymus chinensis hay was closest to the NRC (2001) recommendation
[8]. Diets high in wheat straw in other studies have also shown the effect of controlling energy intake prepartum $[11,12]$. The LD group had significantly higher NDF intake compared with HD group during the last week before parturition. In the last $24 \mathrm{~h}$ before calving, the NDF intake of LD group increased 63\% compared with HD group, but the NEI was similar among the 3 treatment groups. Therefore we could conclude that DMI in the last $24 \mathrm{~h}$ before calving 
Table 3 Effect of energy density of close-up dry period diets on body condition score (BCS) and BW in Holstein cows

\begin{tabular}{|c|c|c|c|c|c|}
\hline \multirow[t]{2}{*}{ Item } & \multicolumn{3}{|c|}{ Dietary treatment ${ }^{1}$} & \multirow[t]{2}{*}{ SEM } & \multirow[t]{2}{*}{$P$-value } \\
\hline & HD & MD & LD & & \\
\hline \multicolumn{6}{|l|}{$\mathrm{BCS}$} \\
\hline Initial BCS & 3.54 & 3.52 & 3.54 & 0.06 & 0.93 \\
\hline Wk -3 to -1 change & 0.02 & 0.00 & -0.04 & 0.02 & 0.27 \\
\hline Wk 1 to 5 change & -0.42 & -0.34 & -0.33 & 0.04 & 0.71 \\
\hline \multicolumn{6}{|l|}{$\mathrm{BW}, \mathrm{kg}$} \\
\hline Initial BW & 632 & 647 & 659 & 8.11 & 0.42 \\
\hline Wk -3 to -1 change & 33.6 & 29.1 & 22.7 & 2.52 & 0.20 \\
\hline Wk 1 to 3 change & -32.1 & -25.3 & -27.4 & 3.25 & 0.73 \\
\hline Wk 1 to 5 change & -57.8 & -49.6 & -47.4 & 3.88 & 0.55 \\
\hline
\end{tabular}

${ }^{1} H D$ high energy density diet, $M D$ middle energy density diet, $L D$ low energy density diet.

was not decided by rumen volume, but rather by energy requirement.

After parturition, LD group had higher DMI compared with HD and MD groups. These results concur with another two studies showing that large changes in DMI prepartum have been related to lower DMI postpartum $[25,26]$. This effect can be explained as follows, 1) the dietary palatability changed more for the LD group from dry cow diet to lactation diet, and the average DMI of the first and second $24 \mathrm{~h}$ periods after calving were $0.6 \mathrm{~kg}$ and $0.7 \mathrm{~kg}$ higher than HD group in this study. 2) Small changes of DMI prepartum may lead to less metabolic disorders which could decrease DMI. Some studies have demonstrated that overfeeding energy prepartum results in a greater number of health problems postpartum $[11,24,27]$.

\section{Lactation performance}

The reduced energy density of close-up diets increased the milk yield, but did not significantly affect $4 \%$ FCM yield. During the first $3 \mathrm{wk}$, average milk yields of the 3 treatments were similar, but the $4 \%$ FCM yield was $2.1 \mathrm{~kg} / \mathrm{d}$ more for HD group than LD group due to a significantly higher milk fat content. Douglas et al. [24] also showed that cows on restricted intake diets prepartum had a numerically higher milk yield (1.5$2.5 \mathrm{~kg} / \mathrm{d}$ ) compared to those on ad libitum intake. On the contrary, cows fed a $150 \%$ of requirement energy diet prepartum tended to produce more milk in wk 1 to 8 than cows fed a $100 \%$ and $80 \%$ requirement energy diets [12]. In the above two studies, milk fat content for cows with more energy consumption prepartum was significantly or numerically higher than lower energy consumption cows which was in agreement with
Table 4 Effect of energy density of close-up dry period diets on milk yield and composition in Holstein cows

\begin{tabular}{ccccccccc}
\hline Item & \multicolumn{3}{c}{ Dietary treatment } & SEM & \multicolumn{4}{c}{$P$-value } \\
& HD & MD & LD & & Diet & Time & Interaction \\
\hline Milk yield, kg/d & & & & & & & \\
Wk 1 to 3 & 32.0 & 32.1 & 32.2 & 0.51 & 0.53 & $<0.001$ & 0.78 \\
Wk 1 to 10 & $36.6^{\mathrm{b}}$ & $38.6^{\mathrm{a}}$ & $38.7^{\mathrm{a}}$ & 0.36 & 0.03 & $<0.001$ & 0.99 \\
4\% FCM yield, kg/d & & & & & & \\
Wk 1 to 3 & 44.0 & 42.4 & 41.9 & 0.78 & 0.55 & $<0.001$ & 0.72 \\
Wk 1 to 6 & 45.4 & 45.7 & 45.4 & 0.54 & 0.90 & $<0.001$ & 0.91 \\
Fat, \% & & & & & & & \\
Wk 1 to 3 & $6.43^{\mathrm{a}}$ & $5.87^{\mathrm{b}}$ & $5.67^{\mathrm{b}}$ & 0.11 & 0.02 & 0.03 & 0.89 \\
Wk 1 to 6 & $5.96^{\mathrm{a}}$ & $5.60^{\mathrm{b}}$ & $5.45^{\mathrm{b}}$ & 0.06 & 0.006 & $<0.001$ & 0.90 \\
Protein, \% & & & & & & & \\
Wk 1 to 3 & 3.66 & 3.65 & 3.67 & 0.05 & 0.97 & $<0.001$ & 0.54 \\
Wk 1 to 6 & 3.50 & 3.45 & 3.48 & 0.02 & 0.69 & $<0.001$ & 0.90 \\
Lactose, \% & & & & & & & \\
Wk 1 to 3 & $4.89^{\mathrm{b}}$ & $5.07^{\mathrm{a}}$ & $5.12^{\mathrm{a}}$ & 0.03 & 0.02 & 0.02 & 0.28 \\
Wk 1 to 6 & 4.99 & 5.10 & 5.12 & 0.04 & 0.06 & 0.002 & 0.12 \\
Fat, kg/d & & & & & & & \\
Wk 1 to 3 & 2.05 & 1.94 & 1.90 & 0.04 & 0.33 & $<0.001$ & 0.70 \\
Wk 1 to 6 & 2.07 & 2.06 & 2.01 & 0.03 & 0.68 & $<0.001$ & 0.89 \\
Protein, kg/d & & & & & & & \\
Wk 1 to 3 & 1.17 & 1.20 & 1.21 & 0.03 & 0.57 & $<0.001$ & 0.55 \\
Wk 1 to 6 & 1.22 & 1.26 & 1.28 & 0.01 & 0.19 & $<0.001$ & 0.94 \\
Wactose, kg/d & & & & & & & \\
Wk 1 to 3 & 1.58 & 1.69 & 1.72 & 0.03 & 0.12 & $<0.001$ & 0.69 \\
\hline
\end{tabular}

${ }^{1} H D$ high energy density diet, $M D$ middle energy density diet, $L D$ low energy density diet.

a, bValues within a row with different superscripts differ significantly at $P<0.05$.

our study. Janovick et al. [12] reported that high milk fat content might be due to a greater mobilization of body stores in the early lactation period. Blood nonesterified fatty acids (NEFA) could account for as much as $40 \%$ of milk fat content on 4 DIM [1]. In this study, the plasma NEFA concentration for HD group was significantly higher than that of LD group during the first 2 wk of lactation $(605.7$ v. $464.8 \mu \mathrm{Eq} / \mathrm{L}$, the data were not published), and the numerically higher BW and BCS loss of HD group could be explained by more mobilization of adipose tissue, which resulted in a high milk fat content. Although milk lactose content is stable, the milk lactose content for HD group was significantly lower than MD and LD groups during the first $3 \mathrm{wk}$ in the current study. A similar result was reported by Janovick et al. [12]. However, this result was not observed by some others $[11,28]$. 
Table 5 Effect of energy density of close-up dry period diets on EB in Holstein cows

\begin{tabular}{|c|c|c|c|c|c|c|c|}
\hline \multirow[t]{2}{*}{ Item } & \multicolumn{3}{|c|}{ Dietary treatment $^{1}$} & \multirow[t]{2}{*}{ SEM } & \multicolumn{3}{|c|}{$P$-value } \\
\hline & HD & MD & LD & & Diet & Time & Interaction \\
\hline \multicolumn{8}{|l|}{$\mathrm{EB}, \mathrm{MJ} /$ day } \\
\hline \multicolumn{8}{|l|}{ Prepartum } \\
\hline$W k-3$ to -1 & $30.1^{\mathrm{a}}$ & $15.9^{b}$ & $1.3^{c}$ & 0.94 & $<0.001$ & $<0.001$ & 0.34 \\
\hline Wk -3 & $42.3^{a}$ & $26.8^{b}$ & $7.5^{c}$ & 3.22 & $<0.001$ & & \\
\hline Wk -2 & $37.2^{a}$ & $20.9^{b}$ & $3.3^{c}$ & 2.93 & $<0.001$ & & \\
\hline Wk -1 & $15.9^{\mathrm{a}}$ & $6.7^{\mathrm{b}}$ & $-8.4^{c}$ & 2.34 & $<0.001$ & & \\
\hline \multicolumn{8}{|l|}{ Postpartum } \\
\hline Wk 1 to 4 & -45.2 & -46.0 & -43.1 & 2.2 & 0.66 & 0.09 & 0.99 \\
\hline Wk 1 & -43.5 & -39.7 & -31.0 & 4.27 & 0.49 & & \\
\hline Wk 2 & -41.0 & -40.2 & -38.9 & 4.06 & 0.98 & & \\
\hline Wk 3 & -51.9 & -53.1 & -52.3 & 4.48 & 0.99 & & \\
\hline Wk 4 & -47.3 & -47.7 & -43.9 & 3.05 & 0.86 & & \\
\hline \multicolumn{8}{|l|}{$\mathrm{EB}, \%$ of requirement } \\
\hline \multicolumn{8}{|l|}{ Prepartum } \\
\hline$W k-3$ to -1 & 149.8 & 126.2 & 101.1 & & & & \\
\hline Wk -1 & 125.6 & 109.7 & 87.4 & & & & \\
\hline \multicolumn{8}{|l|}{ Postpartum } \\
\hline Wk 1 to 4 & 72.7 & 73.1 & 75.2 & & & & \\
\hline Wk 1 & 72.7 & 73.5 & 79.2 & & & & \\
\hline
\end{tabular}

${ }^{1} H D$ high energy density diet, $M D$ middle energy density diet, $L D$, low energy density diet.

$\mathrm{a}, \mathrm{b}$, cValues within a row with different superscripts differ significantly at $P<0.05$.

\section{Energy balance}

Douglas et al. [24] reported that cows fed $6.3 \mathrm{MJ} / \mathrm{kg}$ $\mathrm{NE}_{\mathrm{L}}$ diet in the whole $60 \mathrm{~d}$ dry period consumed an average of $159 \%$ of the NRC (2001) requirements for $\mathrm{NE}_{\mathrm{L}}$. In the current study, cows on moderate or even low energy diets offered ad libitum intake during the close-up period consumed more energy relative to their requirements. The HD group was almost in positive EB in the whole close-up period, but the NEI was markedly lower than requirements due to a sharp decrease in DMI in the last $3 \mathrm{~d}$ before parturation. A $5.4 \mathrm{MJ}$ of $\mathrm{NE}_{\mathrm{L}} / \mathrm{kg}$ diet could meet the energy requirements of cows before d 12, and the NEB became much more serious with the onset of calving. All the 3 treatment cows gained BW prepartum, but LD group lost BCS. Janovick et al. [12] also reported that dry cows offered a diet meeting $80 \%$ of energy requirements lost BCS but gained $18 \mathrm{~kg}$ over the dry period. We could conclude that the increase of BW was attributable to the rapid growth of the fetus and placenta in late pregnancy, and not to maternal BW increase.

Although the average postpartum EB was not significantly affected by prepartum diets, HD group had 3.8 and $12.5 \mathrm{MJ} / \mathrm{d}$ more energy deficiency than MD and LD groups during the first week of lactation, respectively. Other studies have also showed that overfed cows in the dry period were in more NEB postpartum [11,12]. The higher milk fat content for HD group during the first 3 wk of lactation also implied a more marked NEB in the current study.

\section{Conclusions}

Feeding a high energy density diet prepartum resulted in large decline in DMI prepartum, higher milk fat content and lower milk lactose content during the first $3 \mathrm{wk}$ of lactation. The low energy density diet was beneficial in controlling NEI prepartum, increasing milk yield and DMI, and alleviating NEB postpartum.

\section{Abbreviations}

DMl: Dry matter intake; $\mathrm{EB}$ : Energy balance; $\mathrm{NE}_{\mathrm{L}}$ : Net energy for lactation; HD: High energy density diet containing 6.8 MJ NE $/ \mathrm{kg}$; MD: Middle energy density diet containing 6.2 MJ NE $/$ /kg; LD: Low energy density diet contaning 5.4 MJ NE / /kg; DIM: Day in milk; DM: Dry matter; NEB: Negative energy balance; BW: Body weight; BCS: Body condition score; CP: Crude protein; NDF: Neutral detergent fibre; ADF: Acid detergent fibre; NEl: NE $E_{L}$ intake; $N E_{M}$ : Net energy required for maintenance; $N E_{p}$ : Net energy required for pregnancy; EBPRE: Prepartum EB; EBPOST: Postpartum EB.

\section{Competing interests}

The authors declare that they have no competing interests. 


\section{Authors' contributions}

WH, YT, AS, AY and ZW carried out the experiments. SL, ZC and YW participated in the design of the study, and drafted the manuscript. All authors read and approved the final manuscript.

\section{Acknowledgments}

This research was financially supported by National Natural Science Foundation of China $(31272469,31372334)$ and China Agriculture Research System (CARS-37). The authors greatly appreciate all the people who offered assistance in the experimental procedures and paper writing.

Received: 14 March 2014 Accepted: 23 May 2014

Published: 29 May 2014

\section{References}

1. Bell AW: Regulation of organic nutrient metabolism during transition from late pregnancy to early lactation. J Anim Sci 1995, 73:2804-2819.

2. Grummer RR, Wiltbank MC, Fricke PM, Watters RD, Silva-Del-Rio N: Management of dry and transition cows to improve energy balance and reproduction. J Reprod Dev 2010, 56:S22-S28.

3. Bertics SJ, Grummer RR, Cadorniga-Valino C, Stoddard EE: Effect of prepartum dry matter intake on liver triglyceride concentration and early lactation. J Dairy Sci 1992, 75:1914-1922

4. Grummer RR: Impact of changes in organic nutrient metabolism on feeding the transition dairy cow. J Anim Sci 1995, 73:2820-2833.

5. Guo J, Peters RR, Kohn RA: Effect of a transition diet on production performance and metabolism in periparturient dairy cows. J Dairy Sci 2007, 90:5247-5258.

6. Moe PW, Tyrrell HF: Metabolizable energy requirements of pregnant dairy cows. J Dairy Sci 1972, 55:480-483.

7. McNamara S, O'Mara FP, Rath M, Murphy JJ: Effects of different transition diets on dry matter intake, milk production, and milk composition in dairy cows. J Dairy Sci 2003, 86:2397-2408.

8. NRC: Nutrient requirements of dairy cattle. 7th edition. Washington, DC: National Academies Press; 2001

9. Doepel L, Lapierre H, Kennelly Jj: Peripartum performance and metabolism of dairy cows in response to prepartum energy and protein intake. J Dairy Sci 2002, 85:2315-2334.

10. Agenas $S$, Burstedt $E$, Holtenius $K$ : Effects of feeding intensity during the dry period. 1. Feed intake, body weight, and milk production. J Dairy SCi 2003, 86:870-882.

11. Dann HM, Litherland NB, Underwood JP, Bionaz M, D'Angelo A, McFadden JW, Drackley JK: Diets during far-off and close-up dry periods affect periparturient metabolism and lactation in multiparous cows. J Dairy Sci 2006, 89:3563-3577.

12. Janovick NA, Drackley JK: Prepartum dietary management of energy intake affects postpartum intake and lactation performance by primiparous and multiparous Holstein cows. J Dairy Sci 2010, 93:3086-3102.

13. Rukkwamsuk T, Wensing T, Geelen MJ: Effect of overfeeding during the dry period on regulation of adipose tissue metabolism in dairy cows during the periparturient period. J Dairy Sci 1998, 81:2904-2911.

14. Herdt TH: Ruminant adaptation to negative energy balance. Influences on the etiology of ketosis and fatty liver. Vet Clin North Am Food Anim Pract 2000, 16:215-230

15. Bobe G, Young JW, Beitz DC: < i > Invited review: pathology, etiology, prevention, and treatment of fatty liver in dairy cows. J Dairy Sci 2004 87:3105-3124

16. FASS: Guide for the care and use of agricultural animals in research and teaching. 3rd edition. Champaign, IL: Federation of Animal Science Societies; 2010.

17. Chapinal N, Veira DM, Weary DM, von Keyserlingk MAG: Technical note: validation of a system for monitoring individual feeding and drinking behavior and intake in Group-Housed cattle. J Dairy Sci 2007, 90:5732-5736.

18. Lammers BP, Buckmaster DR, Heinrichs AJ: A simple method for the analysis of particle sizes of forage and total mixed rations. J Dairy Sci 1996, 79:922-928.

19. Dann HM, Carter MP, Cotanch KW, Ballard CS, Takano T, Grant RJ: Effect of partial replacement of forage neutral detergent fiber with By-Product neutral detergent fiber in Close-Up diets on periparturient performance of dairy cows. J Dairy Sci 2007, 90:1789-1801.

20. Ferguson JD, Galligan DT, Thomsen N: Principal descriptors of body condition score in Holstein cows. J Dairy Sci 1994, 77:2695-2703.
21. Su H, Wang Y, Zhang $Q$, Wang F, Cao Z, Rahman MA, Cao B, Li S: Responses of energy balance, physiology, and production for transition dairy cows fed with a low-energy prepartum diet during hot season. Trop Anim Health Prod 2013, 45:1495-1503.

22. Minor DJ, Trower SL, Strang BD, Shaver RD, Grummer RR: Effects of nonfiber carbohydrate and niacin on periparturient metabolic status and lactation of dairy cows. J Dairy Sci 1998, 81:189-200.

23. Beever DE: The impact of controlled nutrition during the dry period on dairy cow health, fertility and performance. Anim Reprod Sci 2006, 96:212-226.

24. Douglas GN, Overton TR, Bateman HN, Dann HM, Drackley JK: Prepartal plane of nutrition, regardless of dietary energy source, affects periparturient metabolism and dry matter intake in Holstein cows. J Dairy Sci 2006, 89:2141-2157.

25. Grummer RR, Mashek DG, Hayilli A: Dry matter intake and energy balance in the transition period. Vet Clin North Am Food Anim Pract 2004, 20:447-470.

26. Drackley JK, Dann HM, Douglas GN, Guretzky NAJ, Litherland NB, Underwood JP, Loor JJ: Physiological and pathological adaptations in dairy cows that may increase susceptibility to periparturient diseases and disorders. Ital J Anim Sci 2005, 4:323-344.

27. Janovick NA, Boisclair YR, Drackley JK: Prepartum dietary energy intake affects metabolism and health during the periparturient period in primiparous and multiparous Holstein cows. J Dairy Sci 2011, 94:1385-1400.

28. Rabelo E, Rezende RL, Bertics SJ, Grummer RR: Effects of transition diets varying in dietary energy density on lactation performance and ruminal parameters of dairy cows. J Dairy Sci 2003, 86:916-925.

doi:10.1186/2049-1891-5-30

Cite this article as: Huang et al.: Effect of reduced energy density of close-up diets on dry matter intake, lactation performance and energy balance in multiparous Holstein cows. Journal of Animal Science and Biotechnology 2014 5:30.

\section{Submit your next manuscript to BioMed Central and take full advantage of:}

- Convenient online submission

- Thorough peer review

- No space constraints or color figure charges

- Immediate publication on acceptance

- Inclusion in PubMed, CAS, Scopus and Google Scholar

- Research which is freely available for redistribution 